Nuijten, R. J. M., and B. A. Nolet. 2020. Chains as strong as the weakest link: remote assessment of aquatic resource use on spring migration by Bewick's Swans. Avian Conservation and Ecology 15(2):14. https://doi.org/10.5751/ACE-01682-150214

Copyright (C) 2020 by the author(s). Published here under license by the Resilience Alliance.

Research Paper

\title{
Chains as strong as the weakest link: remote assessment of aquatic resource use on spring migration by Bewick's Swans
}

Rascha J. M. Nuijten ${ }^{1}$ and Bart A. Nolet ${ }^{1,2}$

${ }^{1}$ Department of Animal Ecology, Netherlands Institute of Ecology, Wageningen, The Netherlands, ${ }^{2}$ Department of Theoretical and Computational Ecology, Institute for Biodiversity and Ecosystem Dynamics, University of Amsterdam, Amsterdam, the

Netherlands

\begin{abstract}
Migratory species are threatened worldwide by climate change, overexploitation, and habitat changes. Availability of suitable habitat is important for flying migrants, and in particular for large birds that use the energetically expensive flapping flight mode, such as the Bewick's Swan (Cygnus columbianus bewickii). Bewick's Swans largely feed on aquatic macrophytes during migration that may disappear when nutrient levels, waves, and turbidity exceed certain thresholds. Macrophyte collapse has been suggested as a reason for the sharp decline of the Bewick's Swan population during 1995-2015. We used Bewick's Swans fitted with GPS/GSM neck collars including an accelerometer and water sensor to record the occurrence of aquatic foraging in remote stopovers along their migratory route. We concentrated on spring migration, when stopovers are longer than during autumn, and focused on four key sites identified in earlier tracking studies. Within these sites, we identified areas that are protected based on the World Database on Protected Areas (WDPA). During three years (2017-2019), we obtained a total of 51 complete spring tracks of adult female Bewick's Swans. Most swans showed aquatic foraging along the coast of Estonia and in Dvina Bay, and about half in the Gulf of Finland and Cheskaya Bay. In Estonia and in the Gulf of Finland, swans predominantly used protected zones, but in Dvina Bay swans also foraged extensively in areas that are currently not protected according to WDPA. No protected areas occur in Cheskaya Bay. Macrophyte vegetation is threatened by ongoing or planned construction works in the Gulf of Finland and Dvina Bay, and by future oil and gas exploitation in Cheskaya Bay. Our study shows how migrants can be used as sentinels to pinpoint areas that require protection in order to maintain a chain of suitable stopovers on their migration.
\end{abstract}

\section{Toute chaîne n'est pas plus solide que son maillon le plus faible : évaluation à distance de l'utilisation des ressources aquatiques sur la migration des cygnes de Bewick}

RÉSUMÉ. Les espèces d'oiseaux migrateurs sont menacées dans le monde entier par le changement climatique, la surexploitation et les transformations des habitats. La disponibilité d'un habitat adéquat est importante pour les espèces volantes migratrices et en particulier, pour les gros oiseaux qui utilisent le mécanisme de battement d'ailes, très énergivore. C'est le cas du cygne de Bewick (Cygnus columbianus bewickii). Les cygnes de Bewick se nourrissent principalement de macrophytes aquatiques pendant leur migration. Or, ces derniers peuvent disparaître lorsque les niveaux de nutriments, les vagues et la turbidité dépassent certains seuils. On a émis l'hypothèse que la réduction de la quantité de macrophytes pourrait expliquer le brusque déclin des populations de cygnes de Bewick entre 1995 et 2015. Nous avons équipé des cygnes de Bewick de colliers GPS/GSM dotés d'un accéléromètre et d'un capteur d'eau pour enregistrer l'occurrence de la consommation de végétaux aquatiques lors des escales sur des îles éloignées le long de leur parcours migratoire. Nous nous sommes concentrés sur la migration de printemps, lors de laquelle les arrêts sont plus longs qu'à l'automne, et sur quatre sites clés identifiés lors des études de suivi antérieures. Sur ces sites, nous avons identifié des zones protégées en vertu de la Base de données mondiale sur les aires protégées (WDPA). Pendant trois années (2017-2019), nous avons obtenu en tout 51 suivis complets des itinéraires printaniers empruntés par des cygnes de Bewick femelles adultes. La plupart des cygnes semblaient se nourrir le long de la côte d'Estonie et dans la baie de la Dvina, et la moitié d'entre eux environ se nourrissaient dans le golfe de Finlande et la baie de Cheskaya. En Estonie et dans le golfe de Finlande, les cygnes choisissaient en majorité des zones protégées. En revanche, dans la baie de la Dvina, les cygnes se nourrissaient également dans des zones qui ne sont pas actuellement protégées en vertu de la WDPA. Il n'y a aucune zone protégée dans la baie de Cheskaya. La végétation de macrophytes est menacée par des travaux de construction en cours ou programmés le long du golfe de Finlande et de la baie de la Dvina, et par les projets d'exploitation pétrolière et gazière dans la baie de Cheskaya. Notre étude démontre que les oiseaux migrateurs peuvent servir de sentinelles pour mettre en évidence les zones qui doivent être protégées pour préserver une chaîne d'escales adéquates sur leur route migratoire.

Key Words: Cygnus columbianus bewickii; conservation; fueling; macrophytes; migratory stopover; protected areas; submerged aquatic vegetation; water sensor 


\section{INTRODUCTION}

Migratory species are threatened worldwide by climate change, overexploitation, and habitat changes due to habitat destruction and creation of barriers that impede or prevent movement (Wilcove and Wikelski 2008). The type of habitat changes that cause problems for migratory species depends largely on their type of locomotion. For running and swimming migrants, creation of fences and dams can cause serious obstacles (Hayward and Kerley 2009, Ziv et al. 2012), whereas for flying migrants this is likely to be less of a problem, and availability of suitable habitat is likely to be of more importance.

Two main modes of flight exist: flapping and soaring. Flapping flight is energetically expensive, whereas soaring flight is energetically cheap but dependent on thermal energy, and these flight characteristics have implications for the habitats required for successful migration. For soaring flyers land corridors are essential to cross large water bodies where thermals are weak or absent (Vansteelant et al. 2017), whereas flapping flyers need prime foraging habitat along the migratory route for fueling their flight (Hedenström and Alerstam 1997, Piersma et al. 2016). Because migration speed is mainly determined by fueling rate at stopovers (Alerstam 1991, Lindström et al. 2019), and large birds have low fueling rates (Hedenström and Alerstam 1998, Lindström 2003), suitable stopover habitat is particularly important for large birds using flapping flight. Knowledge about where these birds stop and forage and the food resources at these sites is therefore important for their effective conservation.

Tracking of birds equipped with PTT- or GPS-tags, or for the smaller birds geolocators, has revealed where they stop (Bridge et al. 2011), but such devices generally do not provide information about their foraging behavior. Attempts have been made to derive such information about behavior from (high-frequency) GPS fixes (de Weerd et al.2015), but the addition of extra sensors has greatly improved the ability to record behavior remotely (Wilmers et al. 2015). A well-known example is the sensor that measures static and dynamic acceleration, usually in three directions (Yoda et al. 2001, Kays et al. 2015). By correctly interpreting the resulting data, the behavior of free-ranging individuals at the moment of measurement can be inferred (Shamoun-Baranes et al. 2012, Kölzsch et al. 2016a). This technique has previously been used to measure foraging time and estimate fueling rates of birds (Dokter et al. 2018, van der Kolk et al. 2020). The addition of a water sensor has enabled distinction between terrestrial foraging and aquatic foraging in swans (Nuijten et al. 2020a).

Swans are among the largest species using flapping flight and their migratory distances are thought to be restricted by their fueling time (Hedenström and Alerstam 1998). Tundra Swans (Cygnus columbianus) are migrants breeding on the tundra of North America (nominate subspecies) and Eurasia (subspecies bewickii, called Bewick's Swan), and wintering in temperate regions of these respective continents. Although at the species level it is categorized as Least Concern (Birdlife International 2020), the population breeding on the European Russian tundra and wintering in northwestern Europe is classified as Endangered (Birdlife International 2015). Bewick's Swans need several stopovers to complete their migratory journey, especially in spring (Beekman et al. 2002). Direct observations have revealed that they mainly forage on aquatic macrophytes at these stopover sites (Rees and
Bowler 1991, Nolet et al. 2001a, Zaynagutdinova et al. 2019). Aquatic resources are often preferred, at least by adult swans (Nolet et al. 2002, 2014). The main advantage over terrestrial foraging is that the swans can feed on aquatic macrophytes day and night, whereas on agricultural fields and grasslands foraging is restricted to daytime, supposedly to reduce predation risk (Nolet et al. 2002, 2007).

Macrophytes are ecosystem engineers able to maintain aquatic environmental conditions that are beneficial for themselves as well as a suite of other species, including swans (Scheffer 1990, Jeppesen et al. 1998). Under a wide range of circumstances, macrophytes are able to reduce nutrient levels, waves, and turbidity. When environmental stressors such as eutrophication, increased wave action, or sediment disturbance by, for instance, bottom-dwelling fish exceed a certain threshold, macrophytes may, however, disappear and phytoplankton takes over (Sayer et al. 2010, Phillips et al. 2016). Once a water body has changed to a phytoplankton-dominated state, return to a macrophytedominated state is hampered because nutrient concentrations, water movement, and turbidity are no longer tempered by the presence of macrophytes (Scheffer et al. 1993).

It is known that macrophyte cover changed in some areas but not in others along the southern half of the flyway of northwestern European Bewick's Swans. In Lake Veluwe, The Netherlands $\left(52.4^{\circ} \mathrm{N}, 5.7^{\circ} \mathrm{E}\right)$, macrophytes largely disappeared in the $1970 \mathrm{~s}$ because of eutrophication, but recovered thanks to water purification and biomanipulation measures (van Vierssen et al. 1994), accompanied by disappearance and reappearance of water bird fauna (Noordhuis et al. 2002). In contrast, the macrophyte vegetation of Lake Peipsi on the border between Estonia and Russia $\left(58.7^{\circ} \mathrm{N}, 27.5^{\circ} \mathrm{E}\right)$ is rather stable (Nõges and Nõges 2006), despite fluctuations in nutrient loading (Nõges et al. 2005). Knowledge about macrophyte cover, let alone changes therein, in the more remote northern half of the migratory route is, however, poor. Some attempts have been made to map macrophyte cover along the entirety of the Bewick's Swan migratory route by remote sensing (Beekman et al. 1996), but this has proved to be difficult especially when the macrophytes are totally submerged (Gyimesi et al. 2012a). It has recently been suggested that waterbirds, and swans in particular, may be valuable indicator species of environmental conditions (Wood et al. 2019). Although swans, being large and conspicuous, are among the most easily monitored and observed birds (Marchowski et al. 2018), this may not hold for the entire migratory route because some parts are much less accessible than others, especially in spring. Remote assessment by tagging swans with a water sensors enables the unbiased detection of sites important for aquatic foraging (Nuijten et al. 2020a).

Between 1995 and 2015, Bewick's Swans declined rapidly in northwestern Europe for unknown reasons. A species action plan was adopted that called for maintaining suitable aquatic macrophyte availability at a chain of key sites along the migratory route because these are vital for the swans to complete their migration (Nagy et al. 2012). We fitted Bewick's Swans with GPS/ GSM neck collars including an accelerometer and water sensor, enabling us to remotely assess their use of aquatic resources during migration. Here we concentrate on spring migration, when use of stopovers is longer than during autumn, because in spring 
swans progress with the melting ice, fueling for both migration and reproduction (Nolet 2006, Nuijten et al. 2014). We focused specifically at four main stopover sites identified by a previous tracking study (Nuijten et al. 2014) where we expected a large proportion of the Bewick's Swans to forage on aquatic resources. We also hypothesized that a large proportion would forage aquatically in more than one of these sites. We compare the areas where aquatic foraging was recorded with those currently protected by law, and discuss spatial overlap and potential threats for the sustainability of these important fueling sites for the northwestern European Bewick's Swan and perhaps other migratory waterfowl species.

\section{METHODS}

During December or January of three consecutive winters, 2016/2017, 2017/2018, and 2018/2019, we captured 104 Bewick's Swans in total on agricultural fields in the province of NoordBrabant (The Netherlands) using canon nets. Birds were aged by plumage characteristics and sexed by cloacal inspection; a blood sample was taken for molecular sexing afterward (success rate of cloacal inspection proved 94\%). We fitted individual swans with a GPS/GSM collar. Because swans form stable pair bonds and travel in family groups (Rees et al. 1996, Rees 2006) we targeted adult females in order to prevent tracking individuals belonging to the same pair or family, and because they probably lead the movements to the breeding grounds (Rees 1987). We also tagged immatures, but these were not considered for this study because of the potential nonindependence of the data (eventually, $78 \%$ of the tagged individuals were adult females). The collars were $70 \mathrm{~g}$, with an inner diameter of $51 \mathrm{~mm}$ and a height of $80 \mathrm{~mm}$, colored white with a unique black alpha-numeric code to allow for individual recognition in the field. The collars had solar panels for power supply, and contained a GPS, a tri-axial accelerometer (ACC), and a water sensor, and sent its data remotely via the GSM network to a server on a daily basis. Previous trials in captivity showed that collared swans preened more than their partners without collars during the first four weeks, but no differences in behavior were present thereafter (Nuijten et al. 2014), and the devices were considered safe for the birds.

The sampling frequency of the different sensors was dependent on season and the energy level of the device (Nuijten et al. 2020a). During spring, the period of interest for this study, GPS positions were taken every $15 \mathrm{~min}$, ACC measurements every $2 \mathrm{~min}$ (with a bout duration of $2 \mathrm{~s}$, and bout frequency of $20 \mathrm{~Hz}$ ), and water detection every second (binary) in the collars fitted during the first winter. For the collars fitted during the second and third winters, the measurement frequency of the GPS and ACC sensor was increased to $5 \mathrm{~min}$ and $1 \mathrm{~min}$, respectively. Settings could not be changed after deployment.

The water sensor operated by measuring conductivity, and was triggered when both probes, placed on opposite sides of the collar were submerged (as checked in the lab). We determined whether the water sensor was associated with aquatic foraging by linking positive values to the ACC recordings, more specifically the mean angle of the vertical axis, i.e., parallel to the neck of the swan. An angle of $+90^{\circ}$ or $-90^{\circ}$ corresponds to the neck being straight up or straight down, respectively. For aquatic foraging one would expect the neck to be below the horizontal position (i.e., $<0^{\circ}$ ). For $80 \%$ of all observations for which water was detected $(n=$
439,813), this was indeed the case (Nuijten et al. 2020b). The remaining $20 \%$ at least partly also represents aquatic foraging, because that consists of a sequence of trampling, submerging, and breathing (Brouwer and Tinbergen 1939, Nolet et al. 2001b), and water will be dripping from the collar during trampling and breathing. Another part may consist of incidences in which the swan was resting or preening on open (sea)water with high waves or during periods when heavy rain triggered the water sensor. In order to limit misidentification, we summarized the raw water sensor data to aggregates of $5 \mathrm{~min}$ (i.e., $300 \mathrm{~s}$ ), and specified submergence ("aquatic foraging") to be detected (a total of $>30$ $\mathrm{s}$ " 1 " in raw data) or not ( $>270 \mathrm{~s}$ " 0 " in raw data).

For each individual, we merged the water sensor dataset, i.e., the 5 min aggregates, with the GPS tracking data based on the time stamp attached to both measurements. In case of the $15 \mathrm{~min}$ interval GPS data (for the collars deployed in winter 2016/2017) there could be up to three aggregates of 5 min linked to the same GPS location. We selected the period between 1 Jan and 15 June ("spring migration," including premigratory fueling).

Our focus was at four main stopover sites identified by a previous tracking study (Nuijten et al. 2014), namely (SW and NE corner locations indicated in brackets): the coast of Estonia (21.5E, $57.8 \mathrm{~N}-24.0 \mathrm{E}, 59.2 \mathrm{~N}$ ), the Gulf of Finland near St. Petersburg $(27.9 \mathrm{E}, 59.4 \mathrm{~N}-30.5 \mathrm{E}, 60.7 \mathrm{~N})$, the Dvina Bay $(39.6 \mathrm{E}, 64.5 \mathrm{~N}-$ $40.8 \mathrm{E}, 65.1 \mathrm{~N})$, and Cheskaya Bay (44.8E, 66.5N - 48.0E, 67.8N). Within these stopover sites, we looked at which areas are currently protected based on the World Database on Protected Areas (WDPA; IUCN UNEP-WCMC 2019).

In order to investigate whether aquatic foraging occurred more at some sites than others, and whether this pattern was consistent, we tested whether there were differences in aquatic foraging among the four main sites and the three years using a logistic regression with site and year as fixed factors and individual as random factor to avoid pseudo-replication, using a likelihood ratio test. We ran this analysis using $\mathrm{R}$ package lme4 (Bates et al. 2015). We checked for overdispersion by testing whether the deviation was larger than the mean. The same approach was used to estimate proportions of swans foraging aquatically at at least one, two, three, or four sites, corrected for pseudo-replication.

\section{RESULTS}

We obtained complete spring tracks of 31 individual adult female Bewick's Swans between wintering and summering grounds, during 2017 ( $n=18$ tracks), $2018(n=18)$, and $2019(n=15)$. None of the selected birds flew together. Five individuals were tracked in all three years, 10 individuals were tracked during two of the three years (Table A.1 in Appendix 1). All individuals in general followed the same route from the North Sea countries through the Baltic States, Leningrad Oblast, Karelia, Archangelsk Oblast to Nenets Autonomous Okrug (Figs. A2.1 A and $\mathrm{B}$ in Appendix 2).

Aquatic foraging was recorded in all four main stopover sites. At the west coast of Estonia, many of the swans stopped, mainly using Matsalu Bay, Haapsalu Bay, and Väike Strait where they were foraging aquatically. Further to the north, in the Gulf of Finland, about half of the swans stopped to stage and refuel on aquatic resources. In Dvina Bay again, the majority of swans stopped and foraged aquatically, whereas in Cheskaya Bay 
approximately half did so (Fig. 1). These differences in aquatic resource use among sites were significant $\left(\mathrm{X}_{3}^{2}=18.753, \mathrm{P}=0.0003\right.$; no overdispersion was apparent, with deviation / mean being lower than 1 , namely 0.99 ). The patterns in aquatic resource use by the swans in the different stopovers was almost significantly different among years $\left(\chi_{2}^{2}=4.902, \mathrm{P}=0.086\right)$. The interaction between site and year was not significant $\left(\chi_{6}^{2}=9.028, \mathrm{P}=0.17\right)$ and therefore left out. Nearly all swans foraged aquatically in at least one of these sites, whereas only a minority used aquatic resources in all four main sites during one spring season (Fig. 2).

Fig. 1. Proportion of adult female Bewick's Swans (Cygnus columbianus bewickii) recorded by GPS/GSM tags including a water sensor to forage aquatically in the four main stopover sites during the spring migration of three consecutive years. In total, 31 Individuals were tracked, yielding 18, 18, and 15 tracks in 2017, 2018, and 2019, respectively. Usage of stopover sites was significantly different, with differences among years being almost significant (see main text). Given are means $\pm \mathrm{SE}$ ( $n=3$ years) of proportions estimated by a logistic regression (see main text and Table A3.1 in Appendix 3).

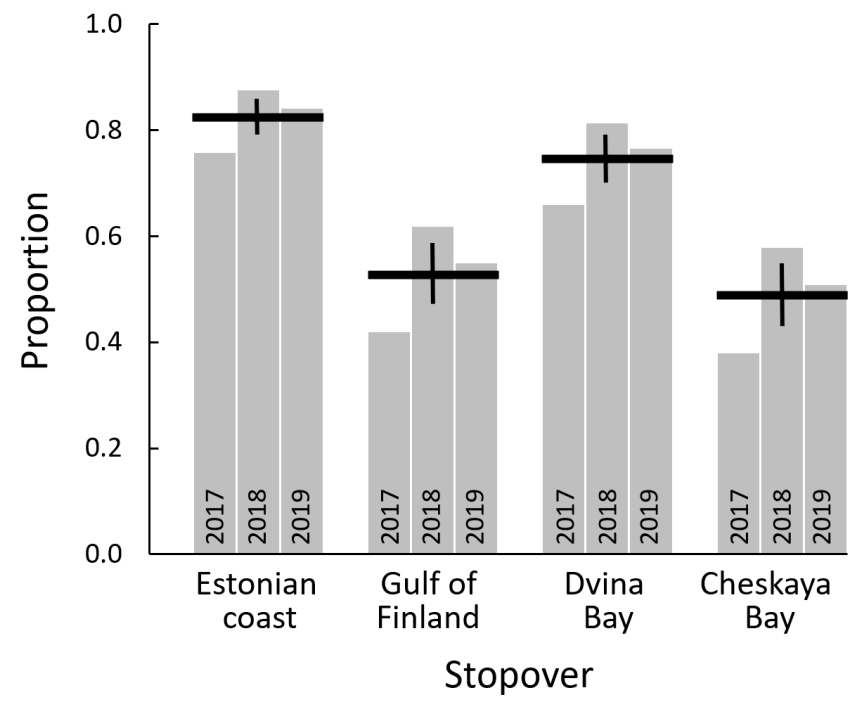

Where present, the swans heavily used protected zones. In Estonia, the swans mainly used Matsalu Bay, Haapsalu Bay, and Väike Strait to fuel for migration, which all have a protected status (Fig. 3). In the Gulf of Finland, they also almost exclusively foraged within the boundaries of the protected areas along the south coast (Fig. 3). In the White Sea, where two protected areas are present in Dvina Bay, the southern one was frequently used for aquatic foraging by the swans (Fig. 3). The other one is a terrestrial protected area enclosing the island of Mud'yug that is not suitable for swans. However, the swans also foraged extensively in areas that are currently not protected in the Dvina Bay, at least according to the WDPA, most noteworthy in the shallow tidal area east of Mud'yug Island (Fig. 3). In Cheskaya Bay there are currently no protected areas listed in the WDPA, but aquatic foraging was recorded there in all three spring seasons (Fig. 3).
Fig. 2. Proportion of adult female Bewick's Swans (Cygnus columbianus bewickii) recorded to forage aquatically in at least one, two, three, or in all four main stopover sites during spring migration of three consecutive years. See Fig. 1 for numbers tracked. Given are means $\pm \mathrm{SE}(n=3$ years) of proportions estimated by a logistic regression (see main text and Table A3.2 in Appendix 3).

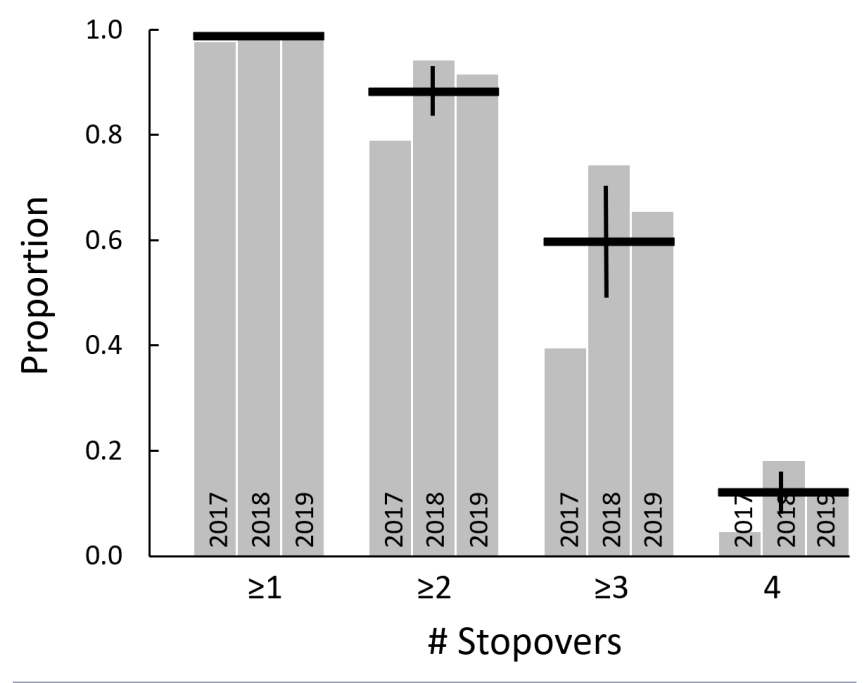

\section{DISCUSSION}

By tracking swans fitted with GPS/GSM tags with an additional accelerometer and water sensor we found that nearly all Bewick's Swans still forage aquatically in at least one of the key stopover sites previously identified, with about half of the swans foraging aquatically in three of those sites. Most swans foraged aquatically along the west coast of Estonia and in Dvina Bay, with lower proportions using aquatic resources in the Gulf of Finland and in Cheskaya Bay. Aquatic foraging mainly took place within protected areas, but with notable exceptions especially in the northern part of the migration route.

The areas where we recorded aquatic foraging by Bewick's Swans during spring migration correspond to important stopovers as identified in earlier tracking studies covering 1993-2011 (Nolet et al. 2001a, Beekman et al. 2002, Nuijten et al. 2014). The major importance of aquatic foraging sites in Estonia is consistent with previous research based on counts and ring readings of Bewick's Swans (Luigujõe et al. 1996). The Gulf of Finland is another important, known stopover area from ground observations, but counts indicate that numbers are presently lower than 20 or more years ago (Zaynagutdinova et al. 2019). Aerial counts of the Dvina Bay followed by direct observations in the shallow tidal area east of Mud'yug Island revealed that this area was used for aquatic foraging by large numbers of Bewick's Swans during the mid-1990s (Nolet et al. 2001a). Much less is known from previous research about Cheskaya Bay during spring. The proportions of swans using $\geq 2$ sites (Fig. 2) highlights the "chain" function that these areas have. 
Fig. 3. Locations used for aquatic foraging by the 31 adult female Bewick's Swans (Cygnus columbianus bewickii) tracked with GPS/GSM transmitters with built-in water sensor during a total of 51 spring migrations. Visualizations for the whole flyway (A), Estonia (B), Gulf of Finland (C), the Dvina Bay (D), and Cheskaya Bay (E). All years (2017, 2018, and 2019) are combined. Every dot indicates a GPS point during which aquatic foraging was identified based on the water sensor data. The black squares in zone A represent the locations of the subsequent zones B-E. The black polygons in zones B-E indicate protected areas as listed in the WDPA (IUCN UNEPWCMC 2019). Aquatic foraging per individual and full GPS/ GSM tracks per individual are presented in Appendix 2, Figs. $\mathrm{A}$ and $\mathrm{B}$, respectively.
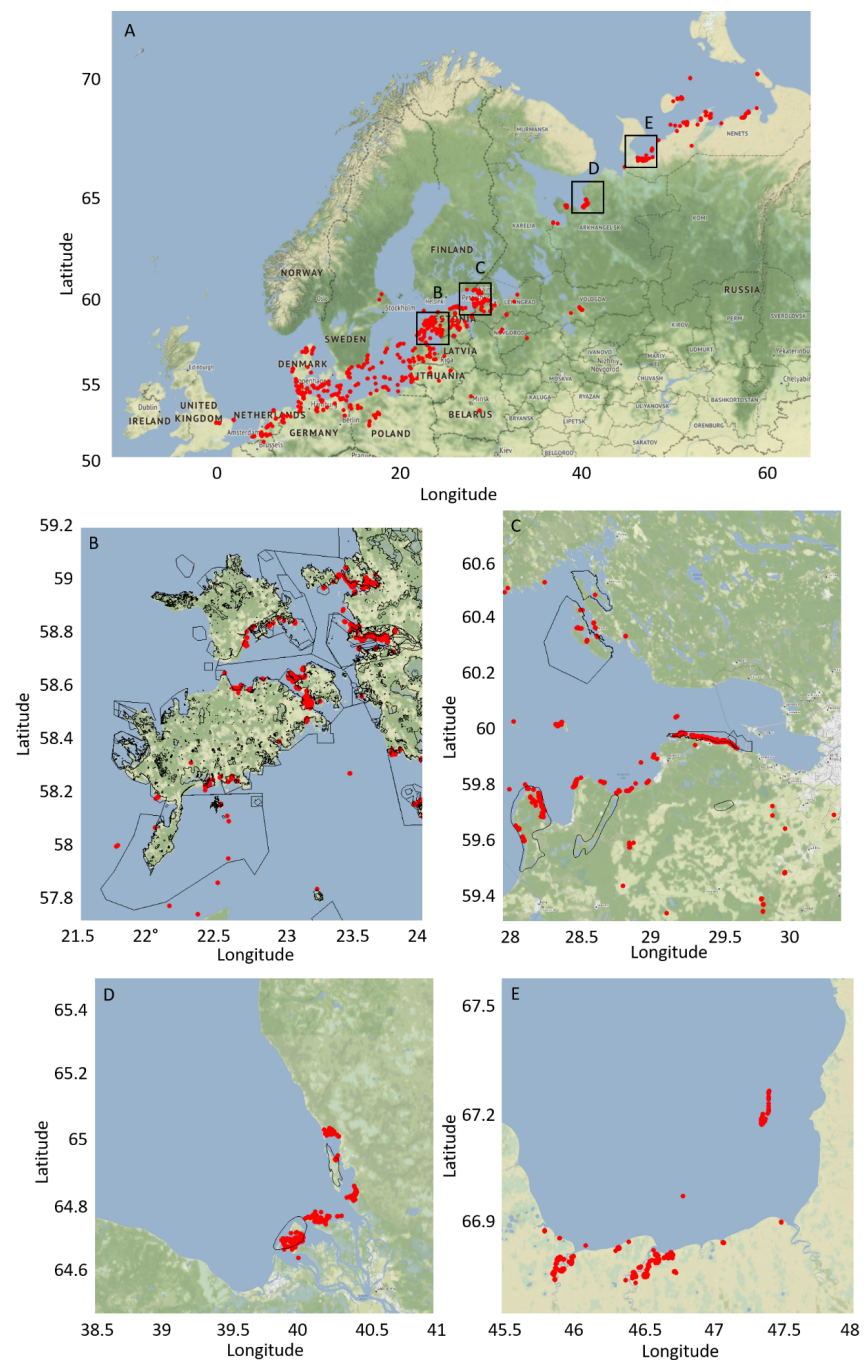

The availability of a chain of suitable stopover habitat is thought to be crucial for successful spring migration and subsequent reproduction. Bewick's Swans in this flyway are slowed by the retreat of ice during spring (Nuijten et al. 2014), a process that varies between years. Dealing with this variation is facilitated by having multiple sites along the route, which enhances predictability of and adjustment to conditions ahead (Kölzsch et al. 2015, Bauer et al. 2020). Based on their migratory speed Bewick's Swans are partly capital breeders (Nolet 2006). This means that they collect stores on their migratory stopovers to fuel both the migration itself and part of the subsequent breeding effort. During autumn, Bewick's Swans do not visit Dvina Bay, likely because they do not need the extra energy for reproduction as they do during spring migration (Beekman et al. 2002). Similarly, White-fronted Geese (Anser albifrons) migrate slower during spring than autumn, using more stopovers, and flying less far to the next stopover for a given time spent at a stopover (Kölzsch et al. 2016b). This again suggests that these geese also fuel during spring for both migration and reproduction, and indeed White-fronted Geese are partly capital breeders (Spaans et al. 1999). Recent work on Barnacle Geese (Branta leucopsis) showed that skipping spring stopovers enables these birds to arrive earlier to the breeding grounds, but not to commence breeding much sooner because they have to refuel first before they can start egg-laying, underlining the importance of spring fueling for successful reproduction (Lameris et al. 2018).

With the loss of natural wetlands over the last 100 years many birds have been forced to look for alternatives. Bewick's Swans are no exception, and in their wintering range they switched to agricultural resources during the 1970s when aquatic vegetation disappeared due to eutrophication (Merne 1972, Mullié and Poorter 1977). Although the aquatic vegetation has recovered in many places, presently swans continue to switch to agricultural resources when aquatic plants become depleted in the course of the winter (Nolet et al. 2002). For a full appreciation of the importance of suitable aquatic stopover sites, one should realize that such alternative terrestrial resources are currently lacking in more northerly sites (Petrie and Wilcox 2003). These more northerly stopover sites are expected to become more important in the future, because waterbirds, including Bewick's swans, are already wintering closer to their breeding grounds in the north (Lehikoinen et al. 2013, Marchowski et al. 2017, Nuijten et al. 2020c).

Although nearly all swans in our study foraged aquatically in at least one of the key sites, more detailed time budgets showed that there was considerable individual variation in the time spent in this behavior (Nuijten et al. 2020a). Previous research indicated that such variation in aquatic foraging during autumn migration was associated with increased body condition prior to spring migration, as well as increased subsequent breeding success (Hoye et al. 2012). Further research is needed to assess the consequences of individual variation in aquatic foraging during spring migration. Differences in the occurrence of aquatic foraging among years seemed to be consistent among sites (the interaction was not significant), suggesting that the swans were not compensating for a lesser use of one stopover site by foraging more aquatically at another site. Differences among years were, however, small.

Whether or not the locations that the swans used for aquatic foraging during their spring migration within the main stopovers were situated inside protected areas varied among sites. In Estonia, these locations were mainly within protected areas. Two sites within the region that the swans use on their spring migration (Vilsandi and Matsalu), with a long history of protection, are now 
protected as National Parks, the highest level of protection in Estonia.

In the Gulf of Finland the aquatic foraging locations were also mostly situated inside protected areas. Here the situation is, however, less secure. Close to the harbor of St. Petersburg, littoral areas have recently been lost because of construction work, but many of these waters were void of aquatic macrophytes, at least during the 1980s (Beekman et al. 1996). Construction work remains a threat, not only leading to direct loss of shallow waters, but also causing massive turbidity that may result in die-off of aquatic macrophytes, underpinning the need to safeguard the areas and their quality in the Finnish Gulf currently in use by the swans, to ensure this site remains available for fueling their migration (Phillips et al. 2016, Zaynagutdinova et al. 2019).

In Dvina Bay there was also extensive aquatic foraging occurring outside protected areas. Although Mud'yug Island itself is a protected area, the area next to it is not, therefore the swans there could be sensitive to changes in hunting, water quality, and industrial developments. Recently, Russia and China together launched a plan to build a deep sea port near Archangelsk to exploit the increasing possibilities of cargo vessels using the new northern sea route that connects western Russia with eastern Asia (Laulajainen 2008, Buxbaum 2018). The new port is planned to be built near Mud'yug Island, just north of the shallow tidal sea, $50 \mathrm{~km}$ from the current port of Archangelsk (Louppova 2018, blog, https://port.today/russia-build-new-deep-port-north/). The location of the port is close to the area intensively used by Bewick's Swans that we tracked in this study during spring 2018. Further developments in the area could threaten the suitability of this site, with potential consequences for the population. Potentially a larger part of Dvina Bay would be affected, as traffic will increase between the new and the current port of Archangelsk.

In Cheskaya Bay, the northernmost stopover site considered in this study, no protected areas were present whereas aquatic foraging was recorded there as well. Cheskaya Bay is a sparsely populated area just above the Arctic Circle. Close to the breeding grounds, this site might be an important "springboard" for the swans, because from here they are likely to be able to predict circumstances in the breeding area and can time their arrival based on this information (Kölzsch et al. 2015). The changing climate has made Arctic Russia of increasing interest for oil and gas exploitation, Cheskaya Bay being no exception (sites TPB1 and TPB2 in Gautier et al. 2009). Further exploitation of these resources may influence the suitability of this stopover site for Bewick's Swans.

Aquatic macrophytes are an important food source not only for Bewick's Swans but also for other migratory waterfowl species in this flyway. Diving ducks often accompany foraging swans and benefit from Potamogeton tubers dug up by swans (Gyimesi et al. 2012b). During the 1990s there was a large seagrass Zostera marina bed in Dvina Bay that was used by Dark-bellied Brant Geese (Branta bernicla bernicla) on their way to Taimyr (Clausen 1997, Green et al. 2002), and construction work near that area is possibly also impacting this species. Similar threats to important wetland stopovers are reported from other flyways, with drastic declines in migratory bird populations as a result (Yang et al. 2011, Piersma et al. 2016, Wu et al. 2020).
Our study shows how avian migrants can be used as sentinels to pinpoint areas that require protection in order to maintain a chain of suitable stopovers on their migration. By tracking over longer time frames, the exciting possibility may arise that we can use tracked animals also as sentinels of environmental conditions (Ropert-Coudert and Wilson 2005, Kays et al. 2015).

Responses to this article can be read online at: http://www.ace-eco.org/issues/responses.php/1682

\section{Acknowledgments:}

We are grateful to everyone who helped with the catching and tagging (Gerard Müskens, Youri van der Horst, Erik Kleyheeg, Peter de Vries, Thomas Lameris, Chiel Boom, Robert van der Meer, Anna Hermsen, Jan Vegelin, Fred Cottaar). Special thanks go to the late Theo Gerrits (madebytheo) for the design and manufacturing of the neck collars. We thank Elmira Zaynagutdinova for providing information about the protection status of sites in Russia, and Henk van der Jeugd for providing comments that helped to improve the manuscript. The tracking study was approved by the Centrale Commissie Dierproeven (license 2016518), and catching and handling was licensed by exemptions Flora- en Faunawet $75 \mathrm{~A}$ obtained through Dienst Regelingen (FF/75/2016/044) and Wet natuurbescherming issued by Omgevingsdienst Brabant Noord (Z/046757). Funding was provided by the Netherlands Organisation for Scientific Research (NWO-NPP grant 866.15.206).

\section{LITERATURE CITED}

Alerstam, T. 1991. Bird flight and optimal migration. Trends in Ecology and Evolution 6:210-215. https://doi.org/10.1016/0169-5347 (91)90024-R

Bates, D., M. Mächler, B. M. Bolker, and S. C. Walker. 2015. Fitting linear mixed-effects models using lme4. Journal of Statistical Software 67. https://doi.org/10.18637/jss.v067.i01

Bauer, S., J. M. McNamara, and Z. Barta. 2020. Environmental variability, reliability of information and the timing of migration. Proceedings of the Royal Society B 287. https://doi.org/10.1098/ rspb.2020.0622

Beekman, J. H., B. A. Nolet, and M. Klaassen. 2002. Skipping swans: fuelling rates and wind conditions determine differential use of migratory stopover sites of Bewick's swans Cygnus bewickii. Ardea 90:437-460.

Beekman, J. H., M. R. van Eerden, Y. N. Mineyev, L. Luigujõe, and H. J. den Hollander. 1996. LANDSAT satellite images for detection of submerged macrophytes: in search of potential stopover feeding sites for Bewick's Swans (Cygnus columbianus bewickii) along their migratory route. Game and Wildlife 13:421-450.

Birdlife International. 2015. European Red List of birds. Office for Official Publications of the European Communities, Luxembourg. 
Birdlife International. 2020. Species factsheet: Cygnus columbianus. Birdlife International, Cambridge, UK. [online] URL: http://datazone.birdlife.org/species/factsheet/tundra-swancygnus-columbianus

Bridge, E. S., K. Thorup, M. S. Bowlin, P. B. Chilson, R. H. Diehl, R. W. Fléron, P. Hartl, R. Kays, J. F. Kelly, W. D. Robinson, and M. Wikelski. 2011. Technology on the move: recent and forthcoming innovations for tracking migratory birds. BioScience 61:689-698. https://doi.org/10.1525/bio.2011.61.9.7

Brouwer, G. A., and L. Tinbergen. 1939. De verspreiding der Kleine Zwanen, Cygnus b. bewickii Yarr., in de Zuiderzee, voor en na de verzoeting. Limosa 12:1-18.

Buxbaum, P. 2018. China and Russia collaborating on Arctic port. Global Trade, 10 January.

Clausen, P. 1997. Dark-bellied brent geese Branta b. bernicla use of the White Sea: a progress report. Pages 174-183 in J. V. Nugteren, editor. Dark-bellied Brent Goose Branta bernicla bernicla flyway management plan. Information and Reference Centre for Nature Management, Ministry of Agriculture, Nature Management and Fisheries. Dutch Society for the Preservation of the Wadden Sea, The Netherlands.

de Weerd, N., F. van Langevelde, H. van Oeveren, B. A. Nolet, A. Kölzsch, H. H. T. Prins, and W. F. de Boer. 2015. Deriving animal behaviour from high-frequency GPS: tracking cows in open and forested habitat. PLOS ONE 10:e0129030. https://doi. org/10.1371/journal.pone.0129030

Dokter, A. M., W. Fokkema, B. S. Ebbinge, H. Olff, H. P. van der Jeugd, and B. A. Nolet. 2018. Agricultural pastures challenge the attractiveness of natural saltmarsh for a migratory goose. Journal of Applied Ecology 55:2707-2718. https://doi.org/10.1111/1365-2664.13168

Gautier, D. L., K. J. Bird, R. R. Charpentier, A. Grantz, D. W. Houseknecht, T. R. Klett, T. E. Moore, J. K. Pitman, C. J. Schenk, J. H. Schuenemeyer, K. Sørensen, M. E. Tennyson, Z. C. Valin, and C. J. Wandrey. 2009. Assessment of undiscovered oil and gas in the Arctic. Science 324:1175-1179. https://doi.org/10.1126/ science. 1169467

Green, M., T. Alerstam, P. Clausen, R. Drent, and B. S. Ebbinge. 2002. Site use by Dark-bellied Brent Geese Branta bernicla bernicla on the Russian tundra as recorded by satellite telemetry: implications for East Atlantic Flyway conservation. Wildlife biology 8:229-239. https://doi.org/10.2981/wlb.2002.028

Gyimesi, A., B. van Lith, and B. A. Nolet. 2012b. Commensal foraging with Bewick's Swans Cygnus bewickii doubles instantaneous intake rate of Common Pochards Aythya ferina. Ardea 100:55-62. https://doi.org/10.5253/078.100.0109

Gyimesi, A., S. Varghese, J. De Leeuw, and B. A. Nolet. $2012 a$. Net energy intake rate as a common currency to explain swan spatial distribution in a shallow lake. Wetlands 32:119-127. https:// doi.org/10.1007/s13157-011-0256-6

Hayward, M. W., and G. I. H. Kerley. 2009. Fencing for conservation: restriction of evolutionary potential or a riposte to threatening processes? Biological Conservation 142:1-13. https:// doi.org/10.1016/j.biocon.2008.09.022
Hedenström, A., and T. Alerstam. 1997. Optimum fuel loads in migratory birds: distinguishing between time and energy minimization. Journal of Theoretical Biology 189:227-234. https:// doi.org/10.1006/jtbi.1997.0505

Hedenström, A., and T. Alerstam. 1998. How fast can birds migrate? Journal of Avian Biology 29:424-432. https://doi. org/10.2307/3677161

Hoye, B. J., S. Hahn, B. A. Nolet, and M. Klaassen. 2012. Habitat use throughout migration: linking individual consistency, prior breeding success and future breeding potential. Journal of Animal Ecology 81:657-666. https://doi.org/10.1111/j.1365-2656.2011.01948. $\mathrm{x}$

IUCN UNEP-WCMC. 2019. The world database on protected areas (WDPA). UNEP World Conservation Monitoring Centre, Cambridge, UK. [online] URL: https://www.protectedplanet. net/

Jeppesen, E., M. Søndergaard, M. Søndergaard, and K. Christofferson, editors. 1998. The structuring role of submerged macrophytes in lakes. Springer, New York, New York, USA. https://doi.org/10.1007/978-1-4612-0695-8

Kays, R., M. C. Crofoot, W. Jetz, and M. Wikelski. 2015. Terrestrial animal tracking as an eye on life and planet. Science 348:aaa2478. https://doi.org/10.1126/science.aaa2478

Kölzsch, A., S. Bauer, R. de Boer, L. Griffin, D. Cabot, K. M. Exo, H. P. van der Jeugd, and B. A. Nolet. 2015. Forecasting spring from afar? Timing of migration and predictability of phenology along different migration routes of an avian herbivore. Journal of Animal Ecology 84:272-283. https://doi.org/10.1111/1365-2656.12281

Kölzsch, A., G. J. D. M. Müskens, H. Kruckenberg, P. Glazov, R. Weinzierl, B. A. Nolet, and M. Wikelski. 2016b. Towards a new understanding of migration timing: slower spring than autumn migration in geese reflects different decision rules for stopover use and departure. Oikos 125:1496-1507. https://doi.org/10.1111/ oik.03121

Kölzsch, A., M. Neefjes, J. Barkway, G. J. D. M. Müskens, F. van Langevelde, W. F. de Boer, H. H. T. Prins, B. H. Cresswell, and B. A. Nolet. 2016a. Neckband or backpack? Differences in tag design and their effects on GPS/accelerometer tracking results in large waterbirds. Animal Biotelemetry 4:13. https://doi. org/10.1186/s40317-016-0104-9

Lameris, T. K., H. P. van der Jeugd, G. Eichhorn, A. M. Dokter, W. Bouten, M. P. Boom, K. E. Litvin, B. J. Ens, and B. A. Nolet. 2018. Arctic Geese tune migration to a warming climate but still suffer from a phenological mismatch. Current Biology 28:2467-2473. https://doi.org/10.1016/j.cub.2018.05.077

Laulajainen, R. 2008. The Arctic sea route. International Journal of Shipping and Transport logistics 1:55-73. https://doi. org/10.1504/IJSTL.2009.021976

Lehikoinen, A., K. Jaatinen, A. V. Vähätalo, P. Clausen, O. Crowe, B. Deceuninck, R. Hearn, C. A. Holt, M. Hornman, V. Keller, L. Nilsson, T. Langendoen, I. Tománková, J. Wahl, and A. D. Fox. 2013. Rapid climate driven shifts in wintering distributions of three common waterbird species. Global Change Biology 19:2071-2081. https://doi.org/10.1111/gcb.12200 
Lindström, A. 2003. Fuel deposition rates in migrating birds: causes, constraints and consequences. Pages 307-320 in E. Berthold, E. Gwinner, and E. Sonnenschein, editors. Avian migration. Springer-Verlag, Berlin, Germany. https://doi. org/10.1007/978-3-662-05957-9_21

Lindström, Å., T. Alerstam, and A. Hedenström. 2019. Faster fuelling is the key to faster migration. Nature Climate Change 9:288-289. https://doi.org/10.1038/s41558-019-0443-7

Luigujõe, L., A. Kuresoo, J. Keskpaik, A. Ader, and A. Leito. 1996. Migration and staging of the Bewick's Swan (Cygnus columbianus bewickii) in Estonia. Game and Wildlife 13:451-461.

Marchowski, D., Ł. Jankowiak, Ł. Ławicki, and D. Wysocki. 2018. Waterbirds counts on large water bodies: comparing ground and aerial methods during different ice conditions. PeerJ 6:e5195. https://doi.org/10.7717/peerj.5195

Marchowski, D., L. Jankowiak, D. Wysocki, Ł. Lawicki, and J. Girjatowicz. 2017. Ducks change wintering patterns due to changing climate in the important wintering waters of the Odra River Estuary. PeerJ 5:e3604. https://doi.org/10.7717/peerj.3604

Merne, O. J. 1972. Bewick's swans feeding on waste potatoes and other agricultural crops. British Birds 65:394-395.

Mullié, W. C., and E. P. R. Poorter. 1977. Aantallen, verspreiding en terreinkeus van de kleine zwaan bij vijf landelijke tellingen in 1976 en 1977. Watervogels 2:85-96.

Nagy, S., N. Petkov, E. Rees, A. Solokha, G. Hilton, J. Beekman, and B. A. Nolet. 2012. International single species action plan for the conservation of the northwest European population of Bewick's Swan (Cygnus columbianus bewickii). Wetlands International and The Wildfowl \& Wetlands Trust (WWT), AEWA Technical Series, (44), Bonn, Germany..

Nõges, P., and T. Nõges. 2006. Indicators and criteria to assess ecological status of the large shallow temperate polymictic lakes Peipsi (Estonia/Russia) and Võrtsjärv (Estonia). Boreal Environment Research 11:67-80.

Nõges, T., R. Laugaste, E. Loigu, I. Nedogarko, B. Skakalski, and P. Nõges. 2005. Is the destabilisation of lake Peipsi ecosystem caused by increased phosphorus loading or decreased nitrogen loading? Water Science and Technology 51:267-274. https://doi. org/10.2166/wst.2005.0600

Nolet, B. A. 2006. Speed of spring migration of Tundra Swans Cygnus columbianus in accordance with income or capital breeding strategy? Ardea 94:579-591.

Nolet, B. A., V. A. Andreev, P. Clausen, M. J. M. Poot, and E. G. J. Wessel. 2001a. Significance of the White Sea as a stopover for Bewick's Swans Cygnus columbianus bewickii in spring. Ibis 143:63-71. https://doi.org/10.1111/j.1474-919x.2001.tb04170.x

Nolet, B. A., R. M. Bevan, M. Klaassen, O. Langevoord, and Y. G. J. T. Van Der Heijden. 2002. Habitat switching by Bewick's swans: maximization of average long-term energy gain? Journal of Animal Ecology 71:979-993. https://doi.org/10.1046/ j.1365-2656.2002.00662.x

Nolet, B. A., T. de Boer, and P. P. de Vries. 2007. Habitat quality estimated from head-dipping time in Trampling Swans. Israel
Journal of Ecology and Evolution 53:317-328. https://doi. org/10.1560/IJEE.53.3.317

Nolet, B. A., A. Gyimesi, and B. van Lith. 2014. Lower foraging efficiency of offspring constrains use of optimal habitat in birds with extended parental care. Ibis 156:387-394. https://doi. org/10.1111/ibi.12137

Nolet, B. A., O. Langevoord, R. M. Bevan, K. R. Engelaar, M. Klaassen, R. J. W. Mulder, and S. Van Dijk. 2001b. Spatial variation in tuber depletion by swans explained by differences in net intake rates. Ecology 82:1655-1667. https://doi.org/10.1890/0012-9658 (2001)082[1655:svitdb]2.0.co;2

Noordhuis, R., D. T. Van der Molen, and M. S. Van den Berg. 2002. Response of herbivorous water-birds to the return of Chara in Lake Veluwemeer, The Netherlands. Aquatic Botany 72:349-367. https://doi.org/10.1016/S0304-3770(01)00210-8

Nuijten, R. J. M., A. Kölzsch, J. A. van Gils, B. J. Hoye, K. Oosterbeek, P. P. de Vries, M. Klaassen, and B. A. Nolet. 2014. The exception to the rule: retreating ice front makes Bewick's swans Cygnus columbianus bewickii migrate slower in spring than in autumn. Journal of Avian Biology 45:113-122. https://doi. org/10.1111/j.1600-048X.2013.00287.X

Nuijten, R. J. M., T. Gerrits, J. Shamoun-baranes, and B. A. Nolet. $2020 a$. Less is more: on-board lossy compression of accelerometer data increases biologging capacity. Journal of Animal Ecology 89:237-247. https://doi.org/10.1111/1365-2656.13164

Nuijten, R. J. M., E. F. Prins, J. Lammers, C. Mager, and B. A. Nolet. 2020b. Calibrating tri-axial accelerometers for remote behavioural observations in Bewick's Swans. Journal of Zoo and Aquarium Research, in press.

Nuijten, R. J. M., K. A. Wood, T. Haitjema, E. C. Rees, and B. A. Nolet. 2020c. Concurrent shifts in wintering distribution and phenology in migratory swans: individual and generational effects. Global Change Biology 26:4263-4275. https://doi. org/10.1111/gcb.15151

Petrie, S. A., and K. L. Wilcox. 2003. Migration chronology of eastern-population Tundra Swans. Canadian Journal of Zoology 81:861-870. https://doi.org/10.1139/z03-063

Phillips, G., N. Willby, and B. Moss. 2016. Submerged macrophyte decline in shallow lakes: What have we learnt in the last forty years? Aquatic Botany 135:37-45. https://doi.org/10.1016/j. aquabot.2016.04.004

Piersma, T., T. Lok, Y. Chen, C. J. Hassell, H. Y. Yang, A. Boyle, M. Slaymaker, Y. C. Chan, D. S. Melville, Z. W. Zhang, and Z. Ma. 2016. Simultaneous declines in summer survival of three shorebird species signals a flyway at risk. Journal of Applied Ecology 53:479-490. https://doi.org/10.1111/1365-2664.12582

Rees, E. C. 1987. Conflict of choice within pairs of Bewick's Swans regarding their migratory movement to and from the wintering grounds. Animal Behaviour 35:1685-1693. https://doi.org/10.1016/ S0003-3472(87)80061-1

\section{Rees, E. C. 2006. The Bewick's Swan. T \& AD Poyser, UK.}

Rees, E. C., and J. M. Bowler. 1991. Feeding activities of Bewick's Swan at migratory site in the Estonian SSR. Wildfowl 1:249-255. 
Rees, E. C., P. Lievesly, R. A. Pettifor, and C. M. Perrins. 1996. Mate fidelity in swans: an interspecific comparison. Pages 118-137 in J. M. Black, editor. Partnerships in birds: the study of monogamy. Oxford University Press, Oxford, UK.

Ropert-Coudert, Y., and R. P. Wilson. 2005. Trends and perspectives in animal-attached remote sensing. Frontiers in Ecology and the Environment 3:437-444. https://doi.org/10.1890/1540-9295 (2005)003[0437:TAPIAR]2.0.CO;2

Sayer, C. D., T. A. Davidson, and J. I. Jones. 2010. Seasonal dynamics of macrophytes and phytoplankton in shallow lakes: a eutrophication-driven pathway from plants to plankton? Freshwater Biology 55:500-513. https://doi.org/10.1111/ j.1365-2427.2009.02365.x

Scheffer, M. 1990. Multiplicity of stable states in freshwater systems. Hydrobiologia 200:475-486.

Scheffer, M., S. H. Hosper, M. L. Meijer, B. Moss, and E. Jeppesen. 1993. Alternative equilibria in shallow lakes. Trends in Ecology and Evolution 8:275-279. https://doi.org/10.1016/0169-5347(93) 90254-M

Shamoun-Baranes, J., R. Bom, E. E. van Loon, B. J. Ens, K. Oosterbeek, and W. Bouten. 2012. From sensor data to animal behaviour: an oystercatcher example. PLoS ONE 7:e37997. https://doi.org/10.1371/journal.pone.0037997

Spaans, B., W. van der Veer, and B. S. Ebbinge. 1999. Cost of incubation in a Greater Whit-fronted Goose. Waterbirds 22:151-155. https://doi.org/10.2307/1522007

van der Kolk, H.-J., B. J. Ens, K. Oosterbeek, W. Bouten, A. M. Allen, M. Frauendorf, T. K. Lameris, T. Oosterbeek, S. Deuzeman, K. de Vries, E. Jongejans, and M. van de Pol. 2020. Shorebird feeding specialists differ in how environmental conditions alter their foraging time. Behavioral Ecology 31:371-382. https://doi.org/10.1093/beheco/arz189

Vansteelant, W. M. G., J. Shamoun-Baranes, W. van Manen, J. van Diermen, and W. Bouten. 2017. Seasonal detours by soaring migrants shaped by wind regimes along the East Atlantic Flyway. Journal of Animal Ecology 86:179-191. https://doi.

org/10.1111/1365-2656.12593

van Vierssen, W., M. Hootsmans, and J. Vermaat, editors. 1994. Lake Veluwe, a macrophyte-dominated system under eutrophication stress. Kluwer Academic, Dordrecht, The Netherlands. https:// doi.org/10.1007/978-94-011-2032-6

Wilcove, D. S., and M. Wikelski. 2008. Going, going, gone: Is animal migration disappearing? PLoS Biology 6:e188. https://doi. org/10.1371/journal.pbio.0060188

Wilmers, C. C., B. Nickel, C. M. Bryce, J. A. Smith, R. E. Wheat, and V. Yovovich. 2015. The golden age of bio-logging: how animal-borne sensors are advancing the frontiers of ecology. Ecology 96:1741-1753. https://doi.org/10.1890/14-1401.1

Wood, K. A., C. Lei, P. Clausen, C. R. Ely, L. Luigujõe, E. C. Rees, J. Snyder, D. V. Solovyeva, and R. Wlodarczyk. 2019. Current trends and future directions in swan research: insights from the 6th International Swan symposium. Wildfowl 5:1-34.

Wu, Y., W. Zhang, F. Yong, D. Zhou, and P. Cui. 2020. Waterbirds' coastal habitat in danger. Science 369:928-929. https://doi. org/10.1126/science.abc 9000

Yang, H. Y., B. Chen, M. Barter, T. Piersma, C. F. Zhou, F. S. Li, and Z. W. Zhang. 2011. Impacts of tidal land reclamation in Bohai Bay, China: ongoing losses of critical Yellow Sea waterbird staging and wintering sites. Bird Conservation International 21:241-259. https://doi.org/10.1017/S0959270911000086

Yoda, K., Y. Naito, K. Sato, A. Takahashi, J. Nishikawa, Y. Ropert-Coudert, M. Kurita, and Y. Le Maho. 2001. A new technique for monitoring the behaviour of free-ranging Adelie penguins. Journal of Experimental Biology:685-690.

Zaynagutdinova, E. M., S. A. Kouzov, P. R. Batova, Y. M. Mikhailov, and A. V Kravchuk. 2019. Spring migration stopovers of swans Cygnus sp. in the Russian part of the Gulf of Finland. Wildfowl 5:123-138.

Ziv, G., E. Baran, S. Nam, I. Rodríguez-Iturbe, and S. A. Levin. 2012. Trading-off fish biodiversity, food security, and hydropower in the Mekong River Basin. Proceedings of the National Academy of Sciences of the United States of America 109:5609-5614. https:// doi.org/10.1073/pnas.1201423109
Editor-in-Chief: Alexander L.Bond

Subject Editor: Jennifer LLavers
Sponsored by the Society of Canadian Ornithologists and Birds Canada

Parrainée par la Société des ornithologistes du Canada et Oiseaux Canada

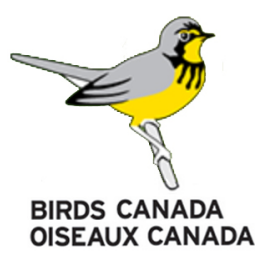




\section{Appendix 1}

Table A1.1. Swan ID and metadata, including whether a spring migration was tracked (1) or not (0). Sites B-E represent the different stopover sites (see Figure 3 in main text).

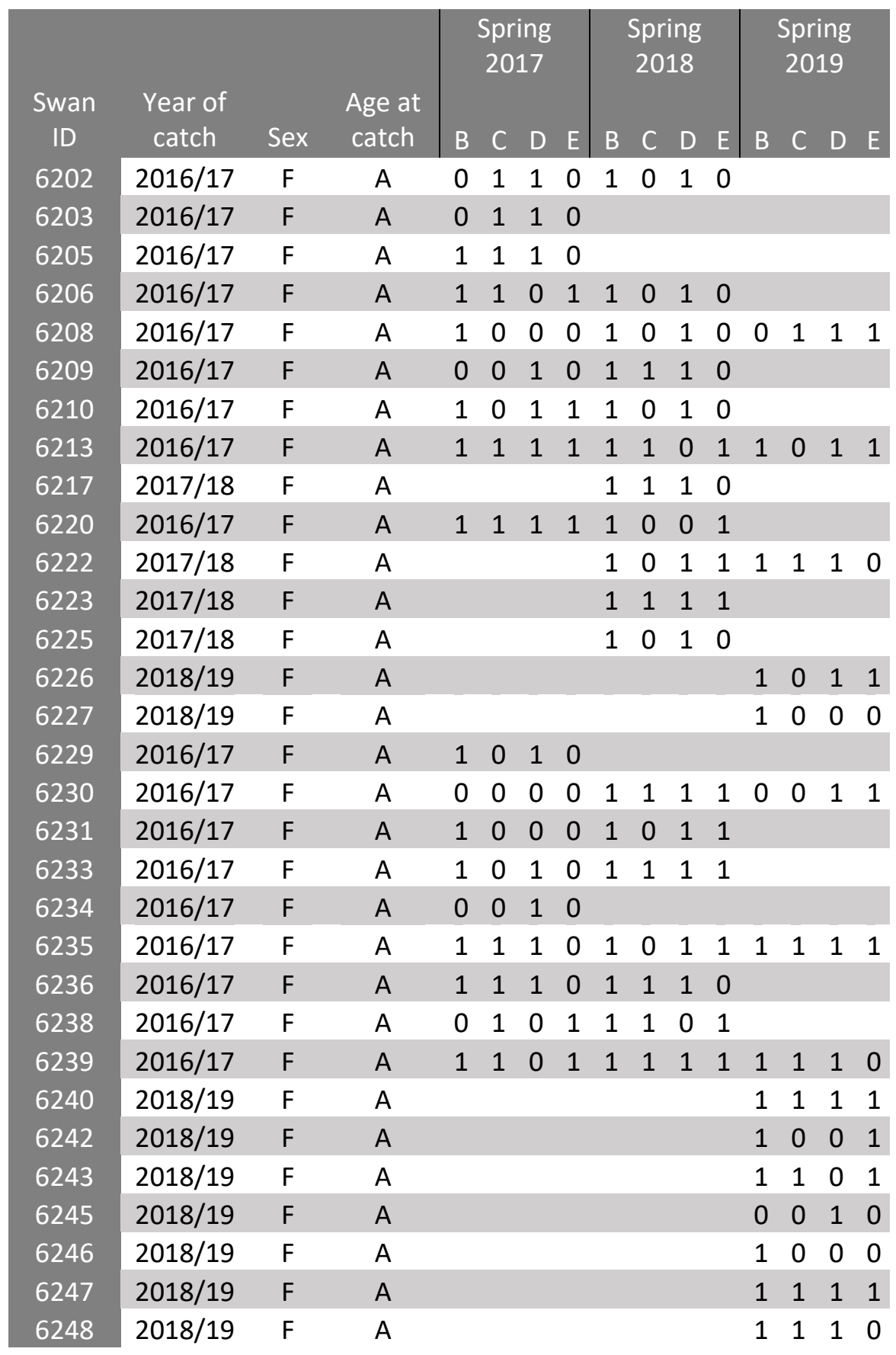




\section{Appendix 2}

Figure A2.1. (A) GPS fixes with aquatic foraging (red) and (B) all GPS (blue) per individual (multiple years combined).

(A)

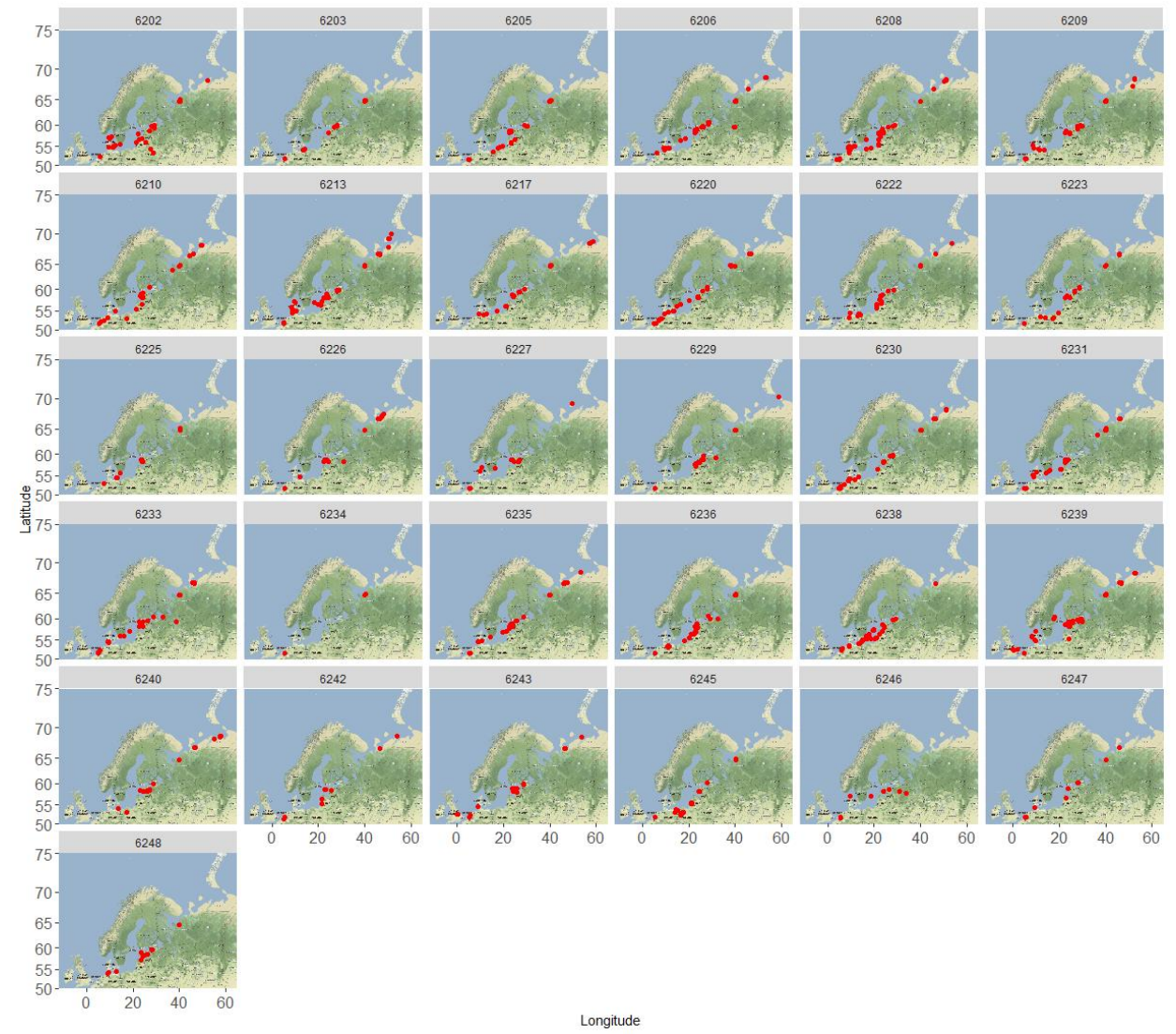


(B)

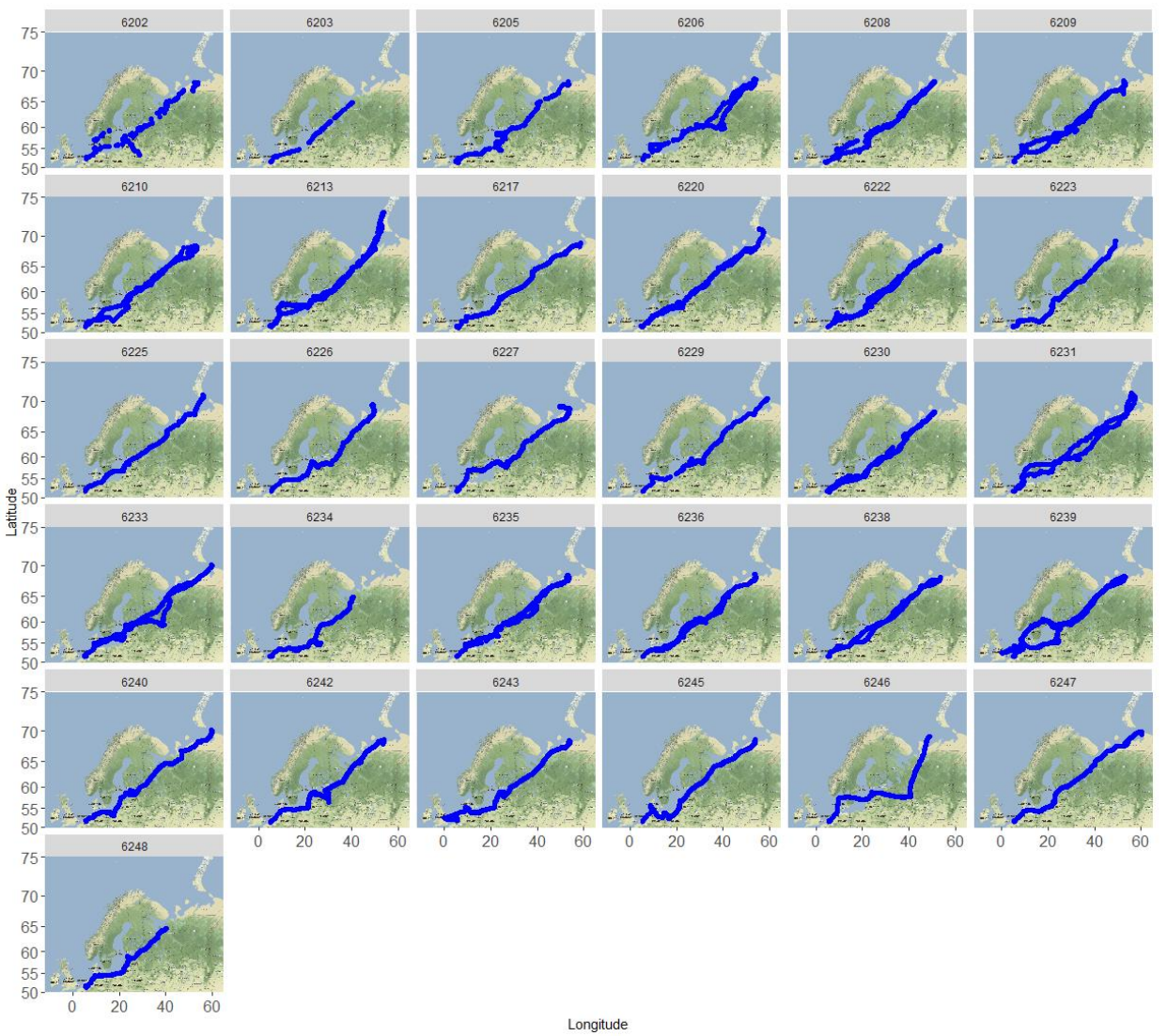




\section{Appendix 3}

Table A3.1. Output logistic regression AQF Site + Spring + (1 | SwanID). Site B, C and D stands for Estonian coast, Gulf of Finland and Dvina Bay, respectively, with Site E (Cheskaya Bay) being the standard. Results visualized in Figure 1 main text.

\begin{tabular}{|l|c|c|c|c|}
\hline & Estimate & Std. Error & z va7ue & $P$ \\
\hline (Intercept) & -0.486 & 0.360 & -1.349 & 0.177 \\
\hline Site B & 1.634 & 0.475 & 3.443 & 0.001 \\
\hline Site C & 0.163 & 0.404 & 0.404 & 0.686 \\
\hline Site D & 1.153 & 0.437 & 2.638 & 0.008 \\
\hline Spring 2018 & 0.809 & 0.376 & 2.152 & 0.031 \\
\hline Spring 2019 & 0.523 & 0.388 & 1.348 & 0.178 \\
\hline
\end{tabular}

Table A3.2. Output logistic regression AQF Number + Spring + (1| SwanID). $\geq 1, \geq 2$ and $\geq 3$ stands for at least one, two and three sites, respectively, with $\geq 4$, at least four sites, being the standard. Results visualized in Figure 2 main text.

\begin{tabular}{|l|c|c|c|l|}
\hline & Estimate & Std. Error & Z value & P \\
\hline (Intercept) & -2.985 & 0.714 & -4.179 & 0.000 \\
\hline$\geq 1$ & 6.797 & 1.293 & 5.258 & 0.000 \\
\hline$\geq 2$ & 4.318 & 0.798 & 5.410 & 0.000 \\
\hline$\geq 3$ & 2.564 & 0.622 & 4.123 & 0.000 \\
\hline Spring 2018 & 1.486 & 0.570 & 2.609 & 0.009 \\
\hline Spring 2019 & 1.068 & 0.645 & 1.656 & 0.098 \\
\hline
\end{tabular}

